\title{
Association of a cytosine-adenine repeat polymorphism in the estrogen receptor $\beta$ gene with occurrence and severity of rheumatoid arthritis
}

\author{
Kanako Watanabe $^{1 *}$, Hiromi Sato ${ }^{1 * \#}$, Ayano Ito ${ }^{1}$, Tomomi Sato ${ }^{1}$, Aránzazu González-Canga ${ }^{2}$, \\ Hana Sugai $^{1}$, Masahiko Suzuki ${ }^{3}$, Takao Namiki ${ }^{4}$, Koichi Ueno $^{1}$ \\ ${ }^{1}$ Department of Geriatric Pharmacology and Therapeutics, Graduate School of Pharmaceutical Sciences, Chiba University, Chiba, \\ Japan \\ ${ }^{2}$ Assessment Area, Medicines for Veterinary Use Department, Agencia Española de Medicamentosy Productos Sanitarios (AEMPS), \\ Madrid, Spain \\ ${ }^{3}$ Research Center for Frontier Medical Engineering, Chiba University, Chiba, Japan \\ ${ }^{4}$ Department of Frontier Japanese-Oriental (Kampo) Medicine, Graduate School of Medicine, Chiba University, Chiba, Japan \\ Email: hiromi-s@,chiba-u.jp
}

Received 16 January 2013; revised 17 February 2013; accepted 26 February 2013

\begin{abstract}
We investigated the influence of the cytosine-adenine (CA) dinucleotide repeat polymorphism in intron 6 of estrogen receptor $\beta(E R \beta)$ gene on rheumatoid arthritis (RA) risk. One hundred and ninety-three RA patients and 77 control subjects with osteoarthritis (OA) were recruited. The CA repeat polymorphism was assayed by a dye-terminator cycle sequencing analysis. No statistically significant difference in the mean number of $C A$ repeats between the $R A$ and $O A$ patients was observed (RA: 21.47, OA: $21.23, P=0.324$ ). The alleles were categorized according to the number of repeats: short $(S, \leqq 21)$ and long $(L, \geqq 22)$, in which the genotypes SS, SL, and LL were observed. No significant differences were observed for the allele and genotype distributions of this polymorphism in both patient groups. The RA patients were classified according to RA severity: mild (least erosive disease) and severe (more erosive and mutilating disease). Again, no significant difference in genotype frequency between these groups was observed, even after stratifying by sex. The present study indicates that additional studies are needed to clarify the roles of this polymorphism, estrogen, and ER in the development of autoimmune diseases.
\end{abstract}

Keywords: Polymorphism; Rheumatoid Arthritis; Sex; Estrogen Receptor $\beta$; CA Repeat

\section{INTRODUCTION}

Rheumatoid arthritis (RA) is the most common chronic

"Kanako Watanabe and Hiromi Sato contributed equally to this work.

${ }^{\#}$ Corresponding author. autoimmune disorder, characterized by chronic inflammation and destruction of the synovial joints, leading to progressive joint deterioration and disability [1]. RA is characterized as a complex genetic disease, meaning that several genes and environmental and stochastic (chance) factors act in concert to cause the pathological events [2]. Principal among the list of known risk factors is sex, as the rate of RA in females is 2 to 3 times higher than that in males [3]. The underlying immune response in RA seems to be influenced by sex hormones, which have been shown to modulate the onset and progression of connective tissue diseases, including RA, in clinical and in vivo studies [4]. In addition, some studies have suggested that female sex hormones and pregnancy are factors possibly associated with RA symptoms. For example, amelioration of RA occurs in approximately three quarters of pregnancies. In these cases, most women who improve experience initial relief in the first trimester, but RA almost invariably recurs within 3 or 4 months after delivery [5]. Another investigation concluded that the menopausal state could be responsible for the major part of the differences in outcome of RA between men and women [6].

To understand the functional role of estrogens in RA development, it is important to study not only estrogens but also the estrogen receptor (ER). Two types of ERs have been identified and cloned: $\operatorname{ER} \alpha$ and $\operatorname{ER} \beta$ [7]. $\operatorname{ER} \alpha$ and $\operatorname{ER} \beta$ are both expressed in synovial tissue, but $\operatorname{ER} \beta$ has been identified as the predominant ER subtype in normal human synovial tissue [8]. The relative ER $\alpha / \operatorname{ER} \beta$ messenger RNA expression ratio was reported to be significantly lower in RA than in non-inflamed synovial tissue [9].

Several studies have investigated the potential roles of 
$\mathrm{ER} \beta(14 \mathrm{q} 22$ - 24) genetic polymorphisms in disease. For example, a cytosine-adenine (CA) dinucleotide repeat in intron 6 and the single nucleotide polymorphism (SNP) rs 1256049 (Rsa polymorphism) have been studied in the context of various human phenotypes, including osteoarthritis [10], bone mineral density [11], and climacteric disorder [12]. In RA, we previously reported that longer $\mathrm{CA}$ repeats in the intron 6 of $\mathrm{ER} \beta$ and the GG genotype at SNP rs1256049 were potential risk factors for RA [13, 14].

In this study, we investigated the association between the CA repeat polymorphism in the intron 6 of the $\operatorname{ER} \beta$ gene and RA in men and women and compared the results obtained with those found in OA patients. In addition, we investigated the relationship between RA severity and CA repeat polymorphism.

\section{SUBJECTS AND METHODS}

\subsection{Subjects and Study Design}

The protocols and procedures for this experiment were approved by the ethics committee of the Graduate School of Pharmaceutical Sciences of Chiba University. All the genetic information used in this study remains confidential.

A total of 270 Japanese patients (222 women and 48 men) from the Chiba University Hospital, Japan, were recruited to participate in this study. These patients belong to 2 groups of subjects: those with rheumatoid arthritis ( $n=193 ; 150$ women and 43 men) and those recruited from the same geographical area and who had osteoarthritis ( $\mathrm{n}=77 ; 72$ women and 5 men), designated as the control subjects. Informed consent was obtained from all subjects who participated in this study.

\subsection{Analysis of the CA Repeat Polymorphisms}

Genomic DNA was extracted from human peripheral blood leukocytes using the QIAamp DNA Mini Kit (Qiagen, Inc., Hilden, Germany) according to the manufacturer's protocol. Polymerase chain reaction (PCR) was performed in $75 \mu \mathrm{L}$ of reaction mixture with the following components: $150 \mathrm{ng}$ of human genomic DNA, oligonucleotide primers designed to amplify polymorphic CA repeats in the intron 6 of the human $\mathrm{ER} \beta$ gene (forward: 5'-CAA TTC CCA ATT CTA AGC CT-3' and reverse: 5'-ATT CTT CTT TAG GCC AGG CA-3') at $0.4 \mu \mathrm{M}$, dNTP mixture (TaKaRa Bio, Inc., Otsu, Japan) at 200 $\mu \mathrm{M}, 7.5 \mu \mathrm{L}$ of $10 \times$ Reaction Buffer (containing $15 \mathrm{mM}$ $\mathrm{MgSO}_{4}$ ) (Transgenomic, Inc., Omaha, USA), and $2.5 \mathrm{U}$ of Optimase Polymerase (Transgenomic, Inc.). The reactions were brought to a total volume of $75 \mu \mathrm{L}$ by adding MilliQ water. The amplification profiles were as follows: 35 cycles of denaturing at $94^{\circ} \mathrm{C}$ for 30 seconds, annealing at $60^{\circ} \mathrm{C}$ for 30 seconds, and extension at $72^{\circ} \mathrm{C}$ for 30 seconds. The PCR products were purified with the QIAquick PCR Purification Kit (Qiagen) and used in the following analysis.

The analysis of the CA repeat polymorphisms was conducted by dye-terminator cycle sequencing using the Dye Terminator Cycle Sequencing Quick Start Kit (Beckman Coulter, Inc. Fullerton, USA) and the CEQ2000 DNA Analysis System (Beckman Coulter, Inc.) according to the manufacturers' protocols.

\subsection{Statistical Analysis}

The allele and genotype frequencies were compared between the patient groups using the Fisher's exact probability test, except for 2 groups (age and the mean numbers of CA repeats), which were compared using the student's t test. $P<0.05$ was considered to represent statistically significant differences for all the analyses.

\section{RESULTS}

The characteristics of the RA and OA patients are shown in Table 1. Significant differences were detected between the RA and OA patients with respect to sex, although in both groups of patients, the occurrence of disease in the women was higher than that in men. In addition, in the female and male groups, the RA patients were significantly younger than the OA patients. We used the same

Table 1. Characteristics of the RA and OA patients.

\begin{tabular}{cccc}
\hline & RA & OA & $P$ value \\
\hline Characteristic & & & \\
All patients (n) & 193 & 77 & \\
Sex (n (\%)) & & & \\
Women & $150(77.7)$ & $72(93.5)$ & $0.001^{\mathrm{a}}$ \\
Men & $43(22.3)$ & $5(6.5)$ & \\
Age (mean (SD, range)) & & & \\
Women & $61.0 \pm 10.8$ & $70.0 \pm 9.33$ & $0.000^{\mathrm{b}}$ \\
& $(24-86)$ & $(50-91)$ & \\
Men & $61.9 \pm 11.00$ & $73.4 \pm 14.15$ & $0.037^{\mathrm{b}}$ \\
Total & $(38-83)$ & $(51-89)$ & \\
(21.2 & $(24-86)$ & $(50-91)$ & $0.000^{\mathrm{b}}$ \\
Severity (n (\%)) & & & \\
LES & $48(24.9)$ & - & \\
MES & $135(69.9)$ & - & \\
MUD & $10(5.2)$ & - & \\
\hline
\end{tabular}

$P$ values are shown for comparisons between RA and OA by athe Fisher's exact probability test and ${ }^{b}$ student's $t$ test. Differences were considered significant at $P<0.05$. LES, least erosive subset; MES, more erosive subset; MUD, mutilating disease. 
criteria as those used by Ochi et al. [15] to classify our patients into 3 severity types (least erosive disease, LES; more erosive disease, MES; and mutilating disease, MUD). These severity classifications were determined by orthopedic specialists based on long-term observation data. Most of the patients in the study were classified as MES, similar to those in our previous study [14].

Figure 1 shows the frequency distribution of the CA repeats in the RA and OA patients. In the RA patients, the number of CA repeats ranged in length from 15 to 28 , with a mean value of 21.47 and a median of 22. In the OA patients, the number of CA repeats ranged in length from 15 repeats to 29 repeats, with a mean value of 21.23 and a median of 22 . The mean numbers of CA repeats were not statistically different between the RA and OA patients $(P=0.324)$. In addition, we categorized 2 allelic types according to the median number of CA repeats: $\leqq 21$ repeats (short allele, S), and $\geqq 22$ repeats (long allele, L). The cutoff value was based on that used in previous studies $[10,12,13]$. Based on these alleles, 3 genotypes (SS, SL and LL) were identified.

The allele and genotype frequency distributions for the $\mathrm{ER} \beta \mathrm{CA}$ repeat polymorphism in the RA and OA patients are shown in Table 2. There were no significant differences observed between the RA and OA patients in this respect. The RA patients were also classified and divided according to sex and RA severity: mild (LES) and severe (MES and MUD). No significant differences in genotype frequency between the RA severity classes were observed before or after stratifying these groups by sex (Table $3)$.

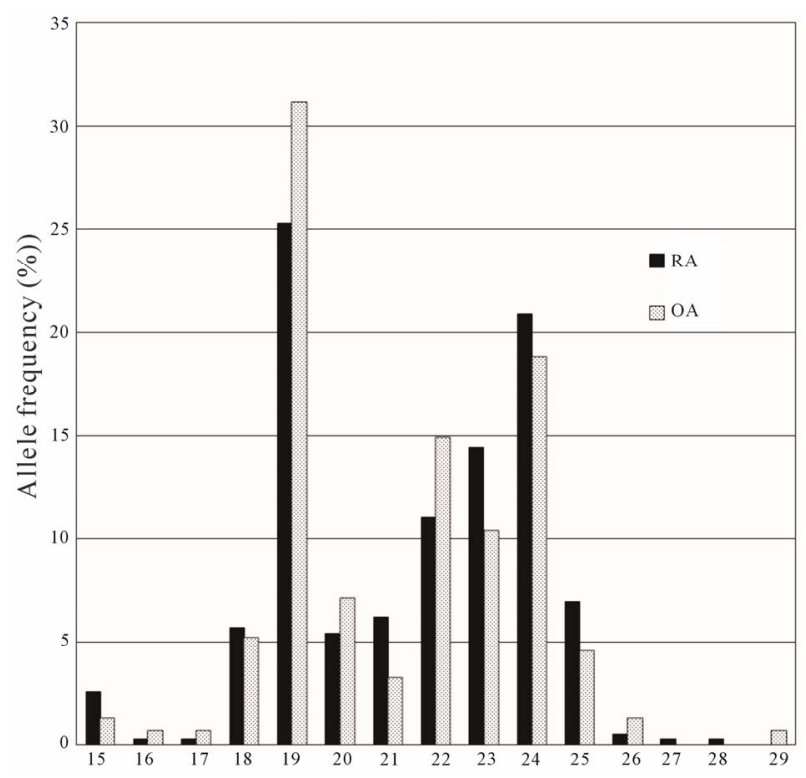

Figure 1. Frequency distribution of alleles at the CA repeat polymorphism in the estrogen receptor $\beta$ gene for the RA and OA patients.
Table 2. Comparison of genotype and allele frequencies for the $\mathrm{ER} \beta$ CA repeat polymorphism in the RA and OA patients.

\begin{tabular}{cccccc}
\hline \multirow{2}{*}{ Genotype } & RA & OA & $\begin{array}{c}\text { Genotype } \\
\text { distribution }\end{array}$ & \multicolumn{2}{c}{$\begin{array}{c}\text { Allele S } \\
\text { vs allele L }\end{array}$} \\
\cline { 2 - 6 } & $\mathrm{n}(\%)$ & $\mathrm{n}(\%)$ & $P$ value & OR $(95 \%$ CI) & $P$ value \\
\hline SS & $48(24.9)$ & $22(28.6)$ & 0.703 & 0.801 & 0.446 \\
SL & $78(40.4)$ & $32(41.5)$ & & $(0.45-1.42)$ & \\
LL & $67(34.7)$ & $23(29.9)$ & & & \\
\hline
\end{tabular}

Differences were considered significant at $P<0.05$ using the Fisher's exact test. OR: Odds ratio; $95 \%$ CI: $95 \%$ confidence interval.

Table 3. Comparison of the genotype and allele frequencies for the ER $\beta$ CA repeat polymorphism between mild (LES) RA, severe (MUD + MES) RA, and OA patients.

\begin{tabular}{cccccc}
\hline & & RA & RA & OA & $\begin{array}{c}\text { Genotype } \\
\text { distribution }\end{array}$ \\
\cline { 3 - 6 } & & $\mathrm{n}(\%)$ & $\mathrm{n}(\%)$ & $\mathrm{n}(\%)$ & $P$ value \\
\hline Female & SS & $7(19.4)$ & $30(26.3)$ & $20(27.8)$ & 0.455 \\
& SL & $21(58.3)$ & $46(40.4)$ & $31(43.0)$ & \\
& LL & $8(22.2)$ & $38(33.3)$ & $21(29.2)$ & \\
Male & SS & $3(25.0)$ & $8(25.8)$ & $2(40.0)$ & 0.985 \\
& SL & $3(25.0)$ & $8(25.8)$ & $1(20.0)$ & \\
& LL & $6(50.0)$ & $15(48.4)$ & $2(40.0)$ & \\
\hline
\end{tabular}

Differences were considered significant at $P<0.05$ using the Fisher's exact test. LES: Least erosive subset; MES: More erosive subset; MUD: Mutilating disease.

\section{DISCUSSION}

We investigated the association of the CA repeat polymorphism in the intron 6 of the $\operatorname{ER} \beta$ gene with RA and OA to follow up on the findings from a previous report [13]; however, our results did not reveal significant differences between RA and OA patients with respect to allele and genotype frequencies identified at this locus.

Based on the patient characteristics (Table 1), we evaluated the degree of severity of RA in the patients according to Ochi et al. [15]. Because this evaluation is primarily dependent on the stages and progress of joint deterioration (e.g., mild or rapid, and oligo arthritis or multi joint), classifications of disease severity are not influenced by differences in sensitivity to drug treatment. Most of the patients enrolled in this study were classified as MES RA, which was consistent with the findings of the previous study by Sato et al. investigating the effects of the ER $\beta$ Rsa polymorphism on RA [14]. Furthermore, in this study, we found that the OA patients were older than the RA patients, which is perhaps not surprising given that OA pathologic features is closely associated with aging. These findings were also similar to those reported by Sato et al. [14]. In the present study, we ana- 
lyzed the CA repeat polymorphism by direct sequencing, a method typically used for the analysis of microsatellite polymorphisms. The mean CA repeat length observed for the RA patients was the same as that reported in a previous study [13]. Thus, neither the patient background nor the methods used for the analyses in the present study are likely to have resulted in the lack of association observed here. Similar patient cohorts were recently used to identify the association between the Rsa polymorphism in the ER $\beta$ gene and RA risk [14]. Considering this, it could be suggested that the Rsa and CA repeat polymorphisms are functionally different, a finding that would not be surprising given that the Rsa polymorphism resides within an exon and the CA repeat polymorphism resides within an intron; however, additional studies are needed to investigate this further.

To date, only a single study has investigated the potential association between the ER $\beta$ CA repeat polymerphism and RA [13]. Wang et al. [16] recently reported that shorter alleles ( $\mathrm{S},<23$ repeats) were marginally associated with increased risk of systemic lupus eryhtematosus (SLE) compared with longer alleles (L, $\geqq 23$ repeats). While it is well known that, like RA, SLE is an autoimmune disease, a link between this polymorphism and RA should not be inferred based solely on the association to SLE [16] given that many differences are known to exist between SLE and RA, such as age at onset and sex differences [17]. Furthermore, Dziedziejko et al. [18] examined the association of SNPs in $\mathrm{ER} \alpha$ and $\mathrm{ER} \beta$ gene with RA but did not observe any significant differences in the distributions of genotypes and alleles between RA patients and controls and no significant association of the genotypes with rheumatoid factor (RF), erosive disease, extra-articular manifestations, or anticyclic citrullinated peptide (anti-CCP) antibodies [18]. In a subsequent study, Dziedziejko et al. [19] also examined potential associations of these SNPs with response to treatment with leflunomide in RA patients but did not reveal a significant association in ER $\beta$ SNPs [19]. Engdahl et al. [20] reported that $\mathrm{ER} \alpha$, but not $\mathrm{ER} \beta$ or GPR-30 signaling, was shown to ameliorate disease and associated development of osteoporosis in a well-established model of postmenopausal RA. These results indicate that the role of $\mathrm{ER} \beta$ in the pathogenesis of RA should be reconsidered.

Furthermore, the effects of estrogen on the development and severity of RA remain controversial, as pro-inflammatory and anti-inflammatory effects have been reported. For example, some selective $\operatorname{ER} \beta$ agonists like ERB-041 are reported to have potent anti-inflammatory effects in animal arthritis models [21], but in a clinical trial, ERB-041 failed to demonstrate anti-inflammatory efficacy in RA patients despite the evidence of strong activity in a preclinical study [22]. Randomized controlled trials conducted by the Women's Health Initiative revealed that there was no significant evidence for a dif- ference in the hazard rate of RA incidence or symptom severity between postmenopausal hormone therapy and placebo groups [23]. Ganesan et al. [24] recently reported protective effects of estrogen and testosterone. This study showed that estrogen had a higher potency in rat arthritic synovial fibroblasts, whereas progesterone was not observed to inhibit TNF- $\alpha$-induced change [24].

In addition to estrogen, other sex hormones have also been implicated in the etiology of RA. For example, the level of dehydroepiandrosterone (DHEA) and DHEA sulfate (DHEAS), the major androgen in women, were associated with the onset of RA [1]. Karlson et al. [25] investigated potential association between androgen levels; polymorphisms in ER $\beta$, PGR, and CYP19 genes; and risk of RA, but no significant associations were observed [25]. To the best of our knowledge, there have been no reported associations between the ER $\beta$ CA repeat polymerphism and sex hormones. Thus, studies assessing potential combinatorial effects of multiple genetic polymorphisms and hormone levels on the risk of RA are warranted.

\section{CONCLUSION}

In conclusion, the results of the present study did not reveal a significant association between alleles at the CA repeat polymorphism in the intron 6 of the $\operatorname{ER} \beta$ gene and RA severity. Additional studies are needed to further clarify potential roles of this polymorphism, as well as roles for estrogen and ER in the pathogenesis and severity of autoimmune diseases.

\section{ACKNOWLEDGEMENTS}

We wish to thank Dr. Yoichi Suzuki of the Medical Faculty of Chiba University for the invaluable help with the genotype analysis. This study was funded by a Grant-in-Aid for Scientific Research (C) from the Japan Society for the Promotion of Sciences and Health Labor Sciences Research Grant.

\section{REFERENCES}

[1] Härle, P., Bongartz, T., Schölmerich, J., Müller-Ladner, U. and Straub, R.H. (2005) Predictive and potentially predictive factors in early arthritis: A multidisciplinary approach. Rheumatology (Oxford), 44, 426-433. doi:10.1093/rheumatology/keh530

[2] Klareskog, L., Catrina, A.I. and Paget, S. (2009) Rheumatoid arthritis. Lancet, 373, 659-672. doi:10.1016/S0140-6736(09)60008-8

[3] Whitacre, C.C. (2001) Sex differences in autoimmune disease. Nature Immunology, 2, 777-780. doi:10.1038/ni0901-777

[4] Cutolo, M., Straub, R.H. and Bijlsma, J.W. (2007) Neuroendocrine-immune interactions in synovitis. Nature Clinical Practice. Rheumatology, 3, 627-634. doi:10.1038/ncprheum0601 
[5] Nelson, J.L. and Ostensen, M. (1997) Pregnancy and rheumatoid arthritis. Rheumatic Diseases Clinics of North America, 23, 195-212. doi:10.1016/S0889-857X(05)70323-9

[6] Kuiper, S., van Gestel, A.M., Swinkels, H.L., de Boo, T.M., da Silva, J.A. and van Riel, P.L. (2001) Influence of sex, age, and menopausal state on the course of early rheumatoid arthritis. The Journal of Rheumatology, $\mathbf{2 8}$, 1809-1816.

[7] Mosselman, S., Polman, J. and Dijkema, R. (1996) ER $\beta$ : Identification and characterization of a novel human estrogen receptor. FEBS Letters, 392, 49-53. doi:10.1016/0014-5793(96)00782-X

[8] Dietrich, W., Haitel, A., Holzer, G., Huber, J.C., Kolbus, A. and Tschugguel, W. (2006) Estrogen receptor- $\beta$ is the predominant estrogen receptor subtype in normal human synovia. Journal of the Society for Gynecologic Investigation, 13, 512-517.

[9] Ishizuka, M., Hatori, M., Suzuki, T., Miki, Y., Darnel, A.D., Tazawa, C., Sawai, T., Uzuki, M., Tanaka, Y., Kokubun, S. and Sasano, H. (2004) Sex steroid receptors in rheumatoid arthritis. Clinical Science, 106, 293-300. doi:10.1042/CS20030317

[10] Fytili, P., Giannatou, E., Papanikolaou, V., Stripeli, F., Karachalios, T., Malizos, K. and Tsezou, A. (2005) Association of repeat polymorphisms in the estrogen receptors $\alpha$, $\beta$, and androgen receptor genes with knee osteoarthritis. Clinical Genetics, 68, 268-277. doi:10.1111/j.1399-0004.2005.00495.x

[11] Shearman, A.M., Karasik, D., Gruenthal, K.M., Demissie, S., Cupples, L.A., Housman, D.E. and Kiel, D.P. (2004) Estrogen receptor beta polymorphisms are associated with bone mass in women and men: The Framingham Study. Journal of Bone and Mineral Research, 19, 773-781. doi:10.1359/jbmr.0301258

[12] Negishi, E., Takeo, C., Nakajima, A., Hisamitsu, K., Amano, K., Hirai, A. and Ueno, K. (2006) Analysis of correlation between prescription drugs for climacteric disorders and CA repeat polymorphism of estrogen receptor $\beta$ gene. Japanese Journal of Pharmaceutical Health Care and Sciences, 32, 21-26. doi:10.5649/jiphcs.32.21

[13] Gonzalez-Canga, A., Ugai, K., Okuzawa, H., Suzuki, M., Okuzawa, H., Negishi, E. and Uneo, K. (2010) Association of cytosin-adenine repeat polymorphism of the estrogen reseptor- $\beta$ gene withrheumatoid arthritis symptoms. Rheumatology International, 30, 1259-1262. doi:10.1007/s00296-010-1423-4

[14] Sato, H., Ito, A., González-Canga, A., Okuzawa, H., Ugai, K., Suzuki, M., Namiki, T. and Ueno, K. (2011) Association of Rsa polymorphism of the estrogen receptor- $\beta$ gene with rheumatoid arthritis. Rheumatology International, 32, 2143-2148. doi:10.1007/s00296-011-1947-2

[15] Ochi, T., Iwase, R., Yonemasu, K., Matsukawa, M., Yoneda, M., Yukioka, M. and Ono, K. (1988) Natural course of joint destruction and fluctuation of serum $\mathrm{C} 1 \mathrm{q}$ levels in patients with rheumatoid arthritis. Arthritis and Rheumatism, 31, 37-43. doi:10.1002/art.1780310106

[16] Wang, J., Nuite, M. and McAlindon, T.E. (2010) Association of estrogen and aromatase gene polymorphisms with systemic lupus erythematosus. Lupus, 19, 734-740. doi:10.1177/0961203309359517

[17] Oliver, J.E. and Silman, A.J. (2009) Why are women predisposed to autoimmune rheumatic diseases? Arthritis Research \& Therapy, 11, 252. doi:10.1186/ar2825

[18] Dziedziejko, V., Kurzawski, M., Safranow, K., Drozdzik, M., Chlubek, D. and Pawlik, A. (2011) Oestrogen recaptor polymorphisms in female patients with rheumatoid arthritis. Scandinavian Journal of Rheumatology, 40, 329333. doi:10.3109/03009742.2011.563752

[19] Dziedziejko, V., Kurzawski, M., Safranow, K., Chlubek, D. and Pawlik, A. (2011) The effect of ESR1 and ESR2 gene polymorphisms on the outcome of rheumatoid arthritis treatment with leflunomide. Pharmacogenomics, 12, 41-47. doi:10.2217/pgs.10.164

[20] Engdahl, C., Jochems, C., Windahl, S.H., Börjesson, A.E., Ohlsson, C., Carlsten, H. and Lagerquist, M.K. (2010) Amelioration of collagen-induced arthritis and immuneassociated bone loss through signaling via estrogen receptor, and not estrogen receptor or $\mathrm{G}$ protein-coupled receptor 30. Arthritis and Rheumatism, 62, 524-533.

[21] Cvoro, A., Tatomer, D., Tee, M.K., Zogovic, T., Harris, H.A. and Leitman, D.C. (2008) Selective estrogen recaptor-beta agonists repress transcription of proinflammatory genes. Journal of Immunology, 180, 630-636.

[22] Roman-Blas, J.A., Castañeda, S., Cutolo, M. and HerreroBeaumont, G. (2010) Efficacy and safety of a selective estrogen receptor agonist, ERB-041, in patients with rheumatoid arthritis: A 12-week, randomized, placebo-controlled, phase II Study. Arthritis Care \& Research, 62, 15881593. doi:10.1002/acr.20275

[23] Walitt, B., Pettinger, M., Weinstein, A., Katz, J., Torner, J., Wasko, M.C., Howard, B.V. and Women's Health Initiative Investigators (2008) Effects of postmenopausal hormone therapy on rheumatoid arthritis: The women's health initiative randomized controlled trials. Arthritis and Rheumatism, 59, 302-310. doi:10.1002/art.23325

[24] Ganesan, K., Balachandran, C., Manohar, B.M. and Puvanakrishnan, R. (2011) Effects of testosterone, estrogen and progesterone on TNF- $\alpha$ mediated cellular damage in rat arthritic synovial fibroblasts. Rheumatology International, 32, 3181-3188. doi:10.1007/s00296-011-2146-X

[25] Karlson, E.W., Chibnik, L.B., McGrath, M., Chang, S.-C., Keenan, B.T., Costenbader, K.H., Fraser, P.A., Tworoger, S., Hankinson, S.E., Lee, I.-M., Buring, J. and De Vivo, I. (2009) A prospective study of androgen levels, hormonerelated genes and risk of rheumatoid arthritis. Arthritis Research \& Therapy, 11, R97. doi:10.1186/ar2742 